\title{
The effect of gender differences on dentist's performance (a study in health centers in East Java)
}

\author{
Titiek Berniyanti $^{1}$ and Kromodiharjo Sudiyono ${ }^{2}$ \\ ${ }^{1}$ Departement of Dental Public Health, Faculty of Dentistry Airlangga University \\ ${ }^{2}$ Departement of Manufacture, Faculty of Tecnology Industry, ITS \\ Surabaya - Indonesia
}

\begin{abstract}
Gender is a social relationship concept that differentiates role and function between man and women. Equality of rights and obligations between man and woman have been normatively guaranteed and the Constitution does not explicitly discriminate the rights and obligations of woman in law and government, in occupation and decent life, in politics, in religion and beliefs, and in national defend. Related with gender perspective, the need of health worker especially dentist worker has to be determined and planned properly. The productivity is one of the factor on dentist worker, that affect on the quality of health delivary. Some companies try to increase efficiency in performing their activities and try to measure activities they do. In this case, time \& motion study method is one of the solutions to help the company measuring their activity. Using these techniques, company can measure the productivity of resources used for every activity. In order to get better performance in cost reduction, the company should assign their cost to the product resulted. Determination of the Standart time to work is one of the method that contain high value of efeciency to gain the productivity. The aim of this study was to learn how gender has an effect on dentist's work performance. The time of completing dentist's task i.e: teeth extraction were measured and the standard time were determined. In addition the patient's respond were measured through questionair. This study was conducted in East Java. The conclusion of this study revealed that there was no difference of work performance between male and female dentist's.
\end{abstract}

Key words: gender, work performance

Correspondence: Titiek Berniyanti, c/o: Bagian Ilmu Kesehatan Gigi Masyarakat, Fakultas Kedokteran Gigi Universitas Airlangga. Jln. Mayjend. Prof. Dr. Moestopo no. 47 Surabaya 60132, Indonesia.

\section{INTRODUCTION}

The study investigated the effect of gender on the dentist's performance, which also implied to the performance of dentists in health centers in East Java. Gender is a social relations concept differentiating the role between man and woman. The differentiation is not due to biological or natural differences. Instead, it is differentiated or divided according to each position, function, and role in various life and development areas. ${ }^{1}$ Natural difference between man and woman comprises four conditions, i.e., menstruation, pregnancy, delivery, and breastfeeding. Equality of rights and obligations between man and woman have been normatively guaranteed by the Constitution 1945. The Constitution does not explicitly discriminate the rights and obligations of woman in law and government, in occupation and decent life, in politics, in religion and beliefs, and in national defend. ${ }^{2}$

Health development is a sector that involving much women. Its percentage, which is slightly higher than man, $50.2 \%$ of Indonesian total population, represents a potentiality to actively take part in health development together with their male counterparts. ${ }^{3}$ According to Ichromi $^{4}$ gender is a social concept. However, different view holds by Abdullah ${ }^{5}$ who regarded that gender is actually a cultural product built on the idea that functionally there are two categories of man and woman. As a cultural product, gender has a hierarchical system that produces operational groups. These groups depend on each other or even compete each other to defend their own power. The efforts to find solution of gender problems in Indonesia had not provided maximum results due to heterogeneous and unclear perception on gender problem in this country. Until now the studies on women in gender perspective is limited only to find aspiration developing among female community. In fact, there were many criteria to evaluate the role of women, i.e.: 1) the extent to which they play a role as participant in development, 2) the extent to which they receive benefit from development, 3) the extent to which they have access to society resources, 4) the extent to which they have control to human resources, including their social facilities.

Hence, it is interesting to know whether or not the gender perspective would effect male or female dentist and give the different result in their productivity. Ergonomics is the study of the interaction between people and machines an the factor that affect the interaction. Its purpose is to improve the performance (work accelerate, accuracy, work safety, reduce work exaggerate and fatigue) of system by improving human machine interaction. ${ }^{6}$ According to Kroemer ${ }^{7}$ success is measured by improved productivity, 
efficiency, safety, acceptance of the resultant system design, and last, but truly not least, improved quality of human life. The concept of individual performance, according to Wignjosubroto, ${ }^{8}$ is the outcome appearance of efforts by an individual. The concept of performance is related with productivity and has a strong correlation with the surrounding systems. There are two ways to accelerate production. The one of them is work simplification. Work simplification or time motion studies is term freely used by engineers who are concerned with improving the efficiency work performed. Time and motion studies were introduced in the USA by Frederick Taylor at the beginning of the 20th century. Since then, the practice has spread throughout the industrialized world. It is a method to increased the productivity, so that production is increased but speed with is accompanying fatigue is reduced. This word in dentistry means shorter and easier way to practice dentistry. Process of analysis applied to a job or number of jobs to check the efficiency of the work method, equipment used, and the worker. Its findings are used to improve performance. ${ }^{9}$

In production theory, system comprises factors providing contribution to the results of production. System in the gender concept refers to social and cultural behavior contributing to gender meaning. Data in Health Office, East Java 1998 showed that since 1988 a community health center has a dentist and dental nurse serving averagely 35 patients a day. ${ }^{10}$ Result of study by Berniyanti ${ }^{10}$ showed that performance produced by a dentist, measured from the capability in diagnosis, aenesthesis and extraction skill in RVU (relative value unit, 1 RVU equal to 5 minutes), indicated that the average work of a dentist was $3 \mathrm{RVU}$ in extracting molar-1.
The purpose of this research is to know whether or not gender differences (Male and Female) have an effect on work performance to raise the productivity. Basically we will be dealing with a synthesis of the two: The application of certain measurement systems for the purpose of analyzing, classifying, and quantifying, that are, work measurement. Work systems consist of integrated activities of people and machines, engaged in the production of goods and services, or in those activities which support that production. Measurement systems are somewhat more abstract. They are integrated activities of people and instrument, use to analyze, classify, and quantify certain attributes of those entities to which they are applied. ${ }^{12}$ Work measurement is an indispensable part of planning and control of an organization. It provides information which is the basis for almost all management decision making.

\section{MATERIAL AND METHOD}

This study used combination of review and quasiexperimental method using the following frame of thinking (Figure 1).

Variables observed was gender perspective, the viewpoint regarding working division according to sex, and performance, the outcome of work measured by working time standard and working quality, including injection precision, extraction skill and working method. Population in this study was divided into two groups, the dentists who carried out tooth extraction and the patients whose tooth was extracted, in community health centers in East Java.

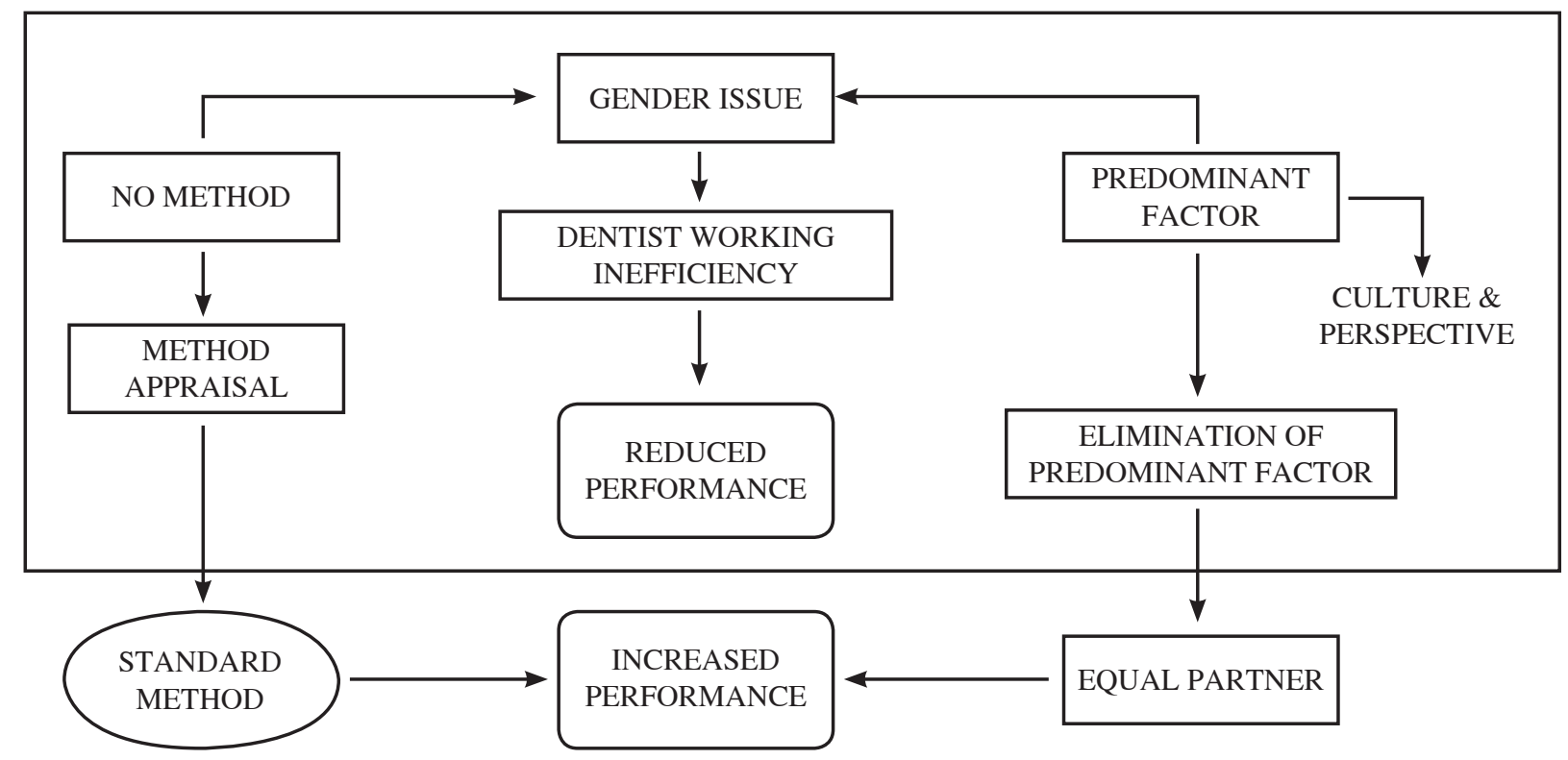

Figure 1. Frame of thinking dentist work performance in Central Health Care Indonesia. 
Using purposive sampling and simple random sampling we obtained 26 dentists and 64 patients as samples in 8 community health centers.

Data collecting was carried out using questionnaire and direct observation to the dentist's working procedure during patient care, based on prevailing standard criteria in international health care, with the following criteria (Table 1, 2, 3, and 4). ${ }^{13}$ This standard is performance rating table that contains score according to the level for each factor. To normalize the time would be carry on by calculating the time acquired from the work measurement, times the sum of four factor's rating chosen according to the performance shown by the operator. ${ }^{7}$ The table of the performance rating can be seen below:

Table 1. Standard criteria observation westinghouse skill ratings system for performance level ${ }^{13}$

\begin{tabular}{ccl}
\hline Score or Rating & Value & Quality \\
\hline+0.15 & A1 & Super-skill \\
+0.13 & A2 & Super-skill \\
+0.11 & B1 & Exellent \\
+0.08 & B2 & Exellent \\
+0.06 & C1 & Good \\
+0.03 & C2 & Good \\
0.00 & D1 & Average \\
-0.05 & E1 & Fair \\
-0.10 & E2 & Fair \\
-0.16 & F1 & Poor \\
-0.22 & F2 & Poor \\
\hline
\end{tabular}

Table 2. Standard criteria observation westinghouse effort ratings system for performance level ${ }^{13}$

\begin{tabular}{ccl}
\hline Score or Rating & Value & Quality \\
\hline+0.13 & A1 & Excessive \\
+0.12 & A2 & Excessive \\
+0.10 & B1 & Exellent \\
+0.08 & B2 & Exellent \\
+0.05 & C1 & Good \\
+0.02 & C2 & Good \\
0.00 & D1 & Average \\
-0.04 & E1 & Fair \\
-0.08 & E2 & Fair \\
-0.12 & F1 & Poor \\
-0.17 & F2 & Poor \\
\hline
\end{tabular}

Table 3. Standard criteria observation westinghouse system condition ratings for performance level $^{13}$

\begin{tabular}{rcl}
\hline Score or Rating & Value & Quality \\
\hline+0.06 & $\mathrm{~A}$ & Ideal \\
+0.04 & $\mathrm{~B}$ & Exellent \\
+0.02 & $\mathrm{C}$ & Good \\
0.00 & $\mathrm{D}$ & Average \\
-0.03 & $\mathrm{E}$ & Fair \\
-0.07 & $\mathrm{~F}$ & Poor \\
\hline
\end{tabular}

Table 4. Standard criteria observation westinghouse system consistency ratings for performance level $^{13}$

\begin{tabular}{ccl}
\hline Score or Rating & Value & Quality \\
\hline+0.04 & $\mathrm{~A}$ & Perfect \\
+0.03 & $\mathrm{~B}$ & Exellent \\
+0.01 & $\mathrm{C}$ & Good \\
0.00 & $\mathrm{D}$ & Average \\
-0.02 & $\mathrm{E}$ & Fair \\
-0.04 & $\mathrm{~F}$ & Poor \\
\hline
\end{tabular}

Data analysis was done using multivariate (T. Hotteling) test and independent two sample t test. Data were interpreted using quantitative and qualitative approach.

\section{RESULTS}

Measurement was conducted for performance variable, comprising diagnosing time and aenesthetic time for the parameter of preparation and the duration of act, as well as extraction time. Measurement was undertaken to the time needed for molar extraction activity. Measurement was also carried out for gender perspective responded by the patient. Results of measurement presented in table 5 were analyzed for the difference of extraction time of male and female dentists. The analysis was divided into two forms, partial analysis for each measured parameter and simultaneous analysis for performance. The result of statistical analysis in each parameter was as follows.

Statistical analysis for each variable was independent two-sample average discriminant test, that was for the variable of diagnosing time, aenesthetic preparation time, and extraction time with the probability value for each 
Table 5. Description of dentist work performance measurement in Central Health Care East Java

\begin{tabular}{lcrcrcr}
\hline & \multicolumn{3}{c}{ Dentist } \\
\hline \multirow{2}{*}{ Variable } & $\mathrm{N}$ & Mean & Male & \multicolumn{2}{c}{ Female } \\
\cline { 3 - 6 } & & 32.869 & 3.101 & Mean & SD \\
\hline Diagnosing time & 26 & 2.802 & 0.434 & 31.969 & 2.996 \\
Preparation time & 26 & 3.021 & 0.635 & 3.307 & 0.473 \\
Extraction time & 26 & & & 0.635 \\
\hline
\end{tabular}

Source: Result of primary data processing

Table 6. Result of two-sample discriminant test of dentist work performance measurement in Central Health Care East Java

\begin{tabular}{rllcc}
\hline Variable & $\mathrm{N}$ & $\mathrm{db}$ & $\mathrm{T}_{\text {count }}$ & prob \\
\hline Diagnosing time & 26 & 50 & 1.065 & 0.292 \\
Preparation time & 26 & 50 & -0.927 & 0.358 \\
Extraction time & 26 & 50 & -1.450 & 0.153 \\
\hline
\end{tabular}

Source: Result of primary data processing

Table 7. Result of two-sample discriminant test of dentist work performance measurement in Central Health Care East Java

\begin{tabular}{ccccc}
\hline Statistical & Value & $\mathrm{db}$ & $\mathrm{F}_{\text {count }}$ & prob \\
\hline Hotteling'S Trace & 0.073 & 3 & 1.164 & 0.333 \\
\hline
\end{tabular}

Resource: Result of primary data processing

Table 8. Result of performance tabulation of dentist work performance measurement in Central Health Care East Java

\begin{tabular}{ccccccccc}
\hline \multirow{2}{*}{$\begin{array}{c}\text { Dentist } \\
\text { groups }\end{array}$} & \multicolumn{4}{c}{ Rating } & \multicolumn{3}{c}{ Quality } \\
\cline { 2 - 9 } & Skill & Effort & Condi & Consy & Skill & Effort & Condi & Consy \\
\hline Male & 0.104 & 0.103 & 0.024 & 0.013 & good & good & good & good \\
Female & 0.103 & 0.099 & 0.025 & 0.001 & good & good & good & good \\
\hline
\end{tabular}

Table 9. Result of two-sample discriminant test of dentist work performance measurement in Central Health Care

\begin{tabular}{ccccc}
\hline Statistical & Value & $\mathrm{db}$ & $\mathrm{F}_{\text {count }}$ & prob \\
\hline Hotteling'S Trace & 0.039 & 4 & 0.457 & 0.676 \\
\hline
\end{tabular}

Resource: Result of primary data processing

statistical test was $t>0.05$. Its is mean that the affect on dependent variable not significant. The summary of multivariate analysis is presented as follows.

Performance observed in this study consisted of skill, effort, condition and consistency with criteria as mentioned in methodology. The following table present performance in both observed groups.
It can be explained that there is no difference in the performance in both gender groups, either in skill, effort, condition or consistency. The result of statistical analysis showed that there is no difference in the performance in both gender groups, either in skill, effort, condition or consistency. 


\section{DISCUSSION}

The result of the above analysis revealed that there was no difference in the variable of diagnosing time, extraction preparation time, and extraction time in both compared male dentist and female dentist groups. Thus, it can be explained that there was no difference in the performance between male dentists and female dentists in terms of their time in completing the task of diagnosing patient, extraction preparation, and extraction. Analysis was also done using multivariate approach, whose results showed no difference in extraction time for measured variables (diagnosis, extraction preparation, aenesthesis, and extraction) for male and female dentist groups.

The gender division of dentist in term of their physical feature is apparent and may affect the predilection of patient to them. However, after being analyzed, there was no significant difference in professional context between male and female dentist. Gender concepts that divide male and female in their role and function apparently does not involve in professional dentistry field. Based on the respondents experience, which was affected by their cognitive and cultural perspective, several substantial questions were delivered in order to describe the trend of dentist preference for dental care.

From 6 items of question responded by the patients representing the community it was found that their perspective on gender was relatively homogeneous. There was no perception difference from the respondents on the male and female dentist performance. These responses indirectly provided justification that gender perspective had actually no effect on working activity, although some experts wrote that in the society there is a set of social relations, which also includes the aspect of power in gender relations. When the gender relations is unbalanced, in which women remains subordinated, other unjust relations may be present in that social relations.

Results obtained in this study, particularly in regard with the patient's response that represents the user of health care, revealed that gender perspective does not affect the dentist performance. Two conclusions can be drawn from this study: no effect of gender difference on dentist activity in community health centers, and no performance difference in gender perspective (male and female dentists).

\section{ACKNOWLEDGMENT}

This article is a part of junior lecturers research funded by human resource development project, Directorate General of Higher Education. In addition to this institution, we also thank to Airlangga University Research Center and all parties who had supported this study.

\section{REFERENCES}

1. Wijaya HR. Mewujudkan kemitraan sejajar laki-laki dan perempuan. 1995. p. 25-27.

2. Gadner O, Wagemmann. M, Sulaeman E, Sulastri. Perempuan Indonesia dulu dan kini. Jakarta: Gramedia Pustaka Utama; 1996. p. 13-25.

3. Wiek W. Identitas dan peran gender. Makalah Seminar. IKIP Malang. 1995.

4. Ichromi. Analisisa gender dan transformasi sosial. Jakarta: Gramedia Pustaka Utama; 1995.

5. Abdullah I. Sangkan paran gender. Jogjakarta: Pustaka Pelajar Offset Gajah Mada; 1997. p. 14-18.

6. Bridger RS. Intoduction to ergonomic. London, New York: Taylor \& Francis Group; 2003. p. 15-17.

7. Kroemer K, Kroemer H, Kroemer-Elbert K. Ergonomic how to design for ease and efficiency. $2^{\text {nd }}$ ed. International Series in Industrial \& System Engineering 2001. p. 1-6.

8. Wignjosubroto $\mathrm{S}$. Teknik tata cara dan pengukuran kerja. Surabaya: ITS; 1993. p. 115-123.

9. Dinas Kesehatan Jawa Timur. Pedoman pelaksanaan pelayanan kesehatan gigi dan mulut. Dinas Kesehatan Jawa Timur. 1998. p. 20.

10. Berniyanti. Penetapan waktu baku dari pencabutan satu gigi dengan metode time motion study di Puskesmas Kodya Surabaya. 1992. p. 1-7.

11. Smith, Geoege L. Work measurement, system approach. Columbus, OHIO: Grid Publishing, Inc; 1978. p. 7-10.

12. Barnes RM. Motion and time study: design and measuremment of work. New York, London: John Wiley and Sons, Inc; 1980. p. 12.

13. Stielle HB. Motion and time study. New York, London: John Wiley and Sons, Inc; 1997. p. 233. 